\title{
TEACHER AND STUDENT TALK IN LEARNING SPEAKING SKILL AT SMA BINA BERSAUDARA MEDAN
}

\author{
AN ARTICLE
}

Submitted in Partial Fulfillment of the Requirements

for the Degree of Sarjana Pendidikan

By:

FATHUL JANNAH HARAHAP

Registration Number: 2163321017

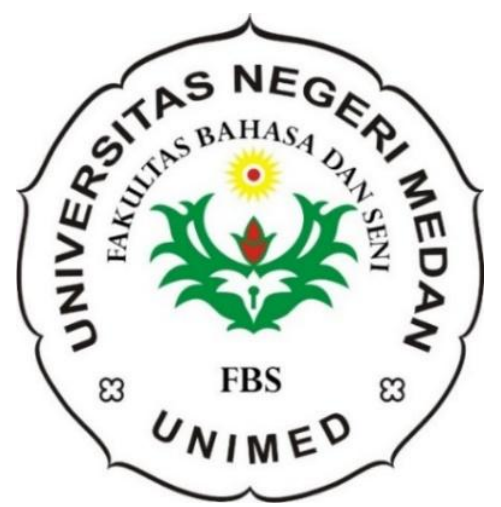

ENGLISH AND LITERATURE DEPARTMENT

FACULTY OF LANGUAGES AND ARTS

UNIVERSITAS NEGERI MEDAN 


\title{
Teacher and Student Talk in Learning Speaking Skill at SMA Bina Bersaudara Medan
}

*Fathul Jannah Harahap

**Indra Hartoyo

\begin{abstract}
This study aimed (1) to investigate the types of teacher and student talk in English classroom interaction and (2) to investigate the teacher and students' reasons to use the types of categories in classroom interaction. This study focuses on analyzing the process of classroom interaction through Flanders Interaction Analysis Categories System (FIACS). This study was conducted by using descriptive qualitative research. It was conducted in SMA Bina Bersaudara Medan at the X-1 grade class. The instruments of the research were observation, recording and interview. The results of this study were (1) the types of teacher talk that occurred were praise or encourages, asking question, lecturing and giving direction. Furthermore, the types of student talk that occurred were response and silence or confusion. (2) There are four reasons why the teacher used the types of categories in classroom interaction, namely: the teacher used praise and encourage to make students feel appreciated, the teacher used asking question because the teacher want to improve students' skill and to make students understood about the topic being discussed before getting into the next topic, the teacher used lecturing to make process of teaching and learning in the classroom to be successful, the teacher used giving direction because teacher wanted to know whether the students have understood about the material or not. There are two reasons why students used the types of categories in classroom interaction, namely: students respond to the teacher because they understood about the topic being discussed, the students wanted to try their ability and to know the extent of their knowledge about the topic, the students silence or confusion when the teacher asked question because the students didn't understand the question given by the teacher, according to them the lesson is very difficult to understood, and they didn't understand the topic being discussed.
\end{abstract}

Keywords: Teacher Talk, Student Talk, Flanders Interaction Analysis Categories System (FIACS).

*Graduate Status 
**Lecturer Status

\section{INTRODUCTION}

Interaction is one important point of success in teaching learning process, because interaction is a collaborative exchange of thought, feeling or ideas between teacher and students or student and other student resulting in reciprocal effect on each other. Interaction between teacher and students plays a significant role in all classroom activities because through the interaction with teacher, students can increase their language store and use all languages they process. Through the interaction, students have opportunities to understand and use the language that was once incomprehensible (Liu and Zhao, 2010). Classroom interaction in English subject is the important part that should be known through the interaction between the teacher-students and among students to see whether it facilitates the language learning or not. Cook (2000: 129) states that teachers should focus on the quality of their talk and

find appropriate forms of teacher talk to make their talk more effective, stimulating, and interesting.

Based on the preliminary observation in X-1 SMA Bina Bersaudara Medan, the researcher found that the interaction between teacher and students in the classroom during teaching learning process such as in the following:

Teacher: Sebelum saya jelaskan, siapa yang tahu apa itu simple future tense? Who knows? (Asking question)

\section{Students: (Silence or confusion)}


Teacher: Kira-kira apa maksud dan bagaimana penggunaan dari simple future tense ini? (Asking question)

\section{Students: (Silence or confusion)}

The classroom interaction showed that the class is dominated by the teacher. During teaching and learning process the teacher often asks questions to students with the aim of making students active and participating in the classroom but students rarely respond when the teacher asks questions about the topic. When interacting in the classroom, teacher used Indonesian more often than English, It can make their interaction ineffective in using English as a target language in their study. That is the basic reason for the researcher to know how the teacher and students interact each other during teaching and learning process in the classroom. To analyze the interaction activities in the classroom, the researcher uses Flanders Interaction Analysis Categories (FIAC) technique. Based on the FIAC, there are three categories in the classroom interaction, namely teacher talk, student talk, and not all talk. Teacher talk includes accept feeling, praises, accept/uses ideas of students, ask question, lecturing, giving direction and criticizing. Student talk includes student talk response, students talk initiation and silence or confusion.

\section{CLASSROOM INTERACTION}

According to Allwright and Ellis in Ma Xiaou (2006), classroom teaching should be treated as interaction. Brown in Dagarin (2004: 128) says that interaction is, in fact, the heart of communication: it is what 
communication is all about. Dagarin (2004: 128) also comments that classroom interaction is two way process between the participants in the learning process.

\section{TEACHER AND STUDENT TALK}

Yanfen\&Yuqin (2010: 76) define teacher talk is an indispensable part of foreign language teaching in organizing activities, and the way teacher talk not only determines how well they make their lectures, but also guarantees how well students will learn. Sinclair \& Brazil in Yanfen\&Yuqin (2010: 77) propose that teacher talk is the language in the classroom that takes up a major portion of class time employed to give directions, explain activities and check students understanding.

\section{FLANDERS INTERACTION ANALYSIS CATEGORIES (FIACS)}

Flanders Interaction Analysis system emphasizes the teaching of the classroom teacher student interaction, which uses a system, taking into account the direct and indirect teaching style behavior classification of the classroom teacher student interaction. Flanders Interaction Analysis Categories (FIAC) is a ten categories system of communication which are said to be inclusive of all communication possibilities. There are seven categories used when the teacher is talking (Teacher talk) and three when the pupil is talking (Student talk).

\section{RESEARCH METHODOLOGY}


The study focuses on teacher and student talk in learning speaking skill at SMA Bina Bersaudara Medan. The research was conducted by using descriptive qualitative research. Bodgan and Taylor in Setiyadi (2006: 219) say that qualitative research is research procedure that results descriptive data in form of written language or human utterances and their behavior that are observed. To get expected data the researcher used Flanders Interaction Analysis Categories (FIAC) system.

\section{RESEARCH FINDINGS AND DISCUSSION}

\section{A. Findings}

\section{The types of teacher and student talk that occurred in English classroom interaction.}

The researcher collected the data from the video recorder and observation in X-1 at SMA Bina Bersaudara Medan. After recording and doing observation, the researcher transcribed and analyzed the video. Based on the transcription that had been analyzed from the video recorder, the types of teacher talk that occurred in the classroom were praise or encourages, asking question, lecturing and giving direction. Furthermore, the types of student talk that occurred in the classroom interaction were response and silence or confusion.

\section{a. The types of teacher talk that occurred in the classroom}

\section{1) Praise or Encourages}


In this case, the teacher gave the student reward by using 'iya benar'. For example:

Teacher:"Sir Bardan sedang bermain bola" who can make it into English? (Asking question)

Student: $\quad$ Sir Bardan is Playing Football (Response)

Teacher: $\quad$ Iya benar. (Praise or Encourages)

\section{2) Asking question}

In this case, the teacher used questions to develop the students speaking and make the students not afraid to talk in the classroom. For example:

Teacher: "Age will..." Apa bahasa Inggris membeli? (Asking Qustion)

3) Lecturing

It occurs when the teacher gives information or explanation about something that is related to the topic lessons.

For example:

Teacher: Simple future tense, tense yang menyatakan suatu kalimat yang dilakukan dimasa yang akan datang. (Lecturing)

\section{4) Giving Direction}

This happened when the teacher started the classroom and asked to students "open book" and gave questions to the students and instructed the students to submit their task. For example: 
Teacher: Terjemahkanlah kalimat berikut kedalam bahasa Inggris dalam bentuk positif, negative dan interogatif. (Giving Direction)

\section{b. The types of student talk that occurred in the classroom}

\section{1) Response}

When the teacher asked them question about the topic being discussed, some of them responded the question given by the teacher. For example:

Teacher: Iya kami ya. Bahasa Inggrisnya kami apa?

Students: We (Response)

\section{2) Silence or Confusion}

In this case, the students silence occurred when the students cannot answer the question given by the teacher or they were confused with what the teacher said at that time. For example:

Teacher: Sekarang apa rumus dari present continuous tense? Apa nak? (Asking Question)

Students: (Silence or confusion)

2. The teacher and students' reasons to use the types of categories in classroom interaction.

The researcher collected the data from interview with the teacher and students in X-1 at SMA Bina Bersaudara Medan. The researcher prepared several questions about teaching and learning process in the 
classroom interaction. After doing interview the researcher found the reasons why the teacher and students used the types of categories in classroom interaction.

a. Teacher's reasons to use the types of categories in classroom interaction.

1) Praise or Encourages

Based on the results of interview the researcher found the reasons why the teacher used that type, as bellow:

Researcher: When you asked questions to students and the students responded to the question, then you gave a positive response to them by saying "yes, that's right", "good", "the smarter you are". What are your reasons for saying these words?

Teacher: Then we know, students like to be praised, even almost all individuals like praise. So that the students can feel appreciated.

\section{2) Asking question}

Based on the results of interview the researcher found the reasons why the teacher used that type, as bellow:

Researcher: During teaching and learning process, you never forgot to ask questions to students about the topic being discussed. What is your purpose of asking question to students during teaching and learning process? 
Teacher: Because I want to improve their skill, and so that before getting into the next topic I want them to understand the topic being discussed.

\section{3) Lecturing}

Based on the results of interview the researcher found the reasons why the teacher used that type, as bellow:

Researcher: During teaching and learning process in the classroom, you always use lecturing method by explaining and describing information to students about the topic being discussed. What are your reasons for using this method in the classroom?

Teacher: In my opinion, one of the ways teaching and learning process to be successful, I have to provide explanations and provide information to my students about the topic.

\section{4) Giving Direction}

Based on the results of interview the researcher found the reasons why the teacher used that type, as bellow:

Researcher: During teaching and learning process, after you explained the topic being discussed, you instructed the students to make example about the topic and you instructed your students to do the exercises. What are your reasons? 
Teacher: By instructing students to make examples, I can find out whether they already understand or not about the material I explain to them.

b. Students' reasons to use the types of categories in classroom interaction.

The types of student talk that occurred in the classroom interaction were response and silence or confusion.

\section{1) Response}

Based on the results of interview the researcher found the students reasons, as bellow:

Researcher: When the teacher asks question or asks you to make one example about the topic being discuss in the classroom, then you respond the question given by the teacher. What are your reasons want to respond?

Student 1: Because I know the answer to the question and to get a good grades from the teacher.

Student 2: I want to try my ability about English.

\section{2) Silence and Confusion}

Based on the results of interview the researcher found the students reasons, as bellow: 
Researcher: When the teacher asks question or asks you to make one example about the topic being discussed in the classroom, you did not respond the question given by the teacher. What are your reasons?

Student 1: Because I don't understand to the questions given by the teacher.

Student 2: Because the lesson is very difficult to understand.

\section{B. Discussion}

This study used FIAC technique to investigate the types of teacher and student talk that occurred in the classroom interaction and to investigate the teacher and students' reasons used the types of categories Based on the results of data analysis, the types of teacher and student talk that occurred in the classroom interaction, as follows: Praise or encourages, praised given by the teacher can make students confident to interact in the classroom. These are related to Flanders Interaction Analysis Categories (1989) which says that praises or encourage is teacher encourages the student action behavior. Asking question, the teacher used to make students understand about the topic being discussed before getting into the next topic. These are related to Flanders Interaction Analysis Categories (1989) which says that asking questions is asking a question about content or procedure is based on teacher ideas, with as intent that a student will answer. Lecturing, the teacher used lecturing to make process of teaching and learning in the classroom to be successful. These are related to Flanders Interaction Analysis Categories 
(1989) which says that lecturing is giving facts or opinions about the content or procedures. Giving direction, the teacher used giving direction because the teacher wants to know whether the students have understood about the material or not. These are related to Flanders Interaction Analysis Categories (1989) which says that giving direction is directions, commands or orders to which a student is expected to comply. Response, students respond to the teacher because they understood about the topic being discussed, the students want to get a good grades from the teacher. These are related to Interaction Analysis Categories (1989) which says that student talk response is talk by students in response to teacher. Silence or confusion, students silence or confusion when the teacher asked question because the students didn't understand to the question given by the teacher. These are related to Flanders Interaction Analysis Categories (1989) which says that silence or confusion is pauses, short periods of silence and period of confusion in which communication cannot be understood by the observer.

\section{CONCLUSIONS AND SUGGESTIONS}

\section{A. Conclusions}

The results of teacher and student talk in learning speaking skill at SMA Bina Bersaudara Medan can be concluded as follows:

1) Based on the transcription that had been analyzed from the video recorder, the types of teacher talk that occurred in X-1 at SMA Bina Bersaudara Medan were praise or encourages, asking question, 
lecturing and giving direction. Furthermore, the types of student talk that occurred in X-1 SMA Bina Bersaudara Medan were response and silence or confusion.

2) There are four reasons why the teacher used the types of categories in classroom interaction, namely: the teacher used praise and encourage to make students feel appreciated, the teacher used asking question because the teacher want to improve students' skill and to make students understood about the topic being discussed before getting into the next topic, the teacher used lecturing to make process of teaching and learning in the classroom to be successful, the teacher used giving direction because teacher wanted to know whether the students have understood about the material or not. There are two reasons why students used the types of categories in classroom interaction, namely: students respond to the teacher because they understood about the topic being discussed, the students wanted to try their ability and to know the extent of their knowledge about the topic, the students silence or confusion when the teacher asked question because the students didn't understand the question given by the teacher, according to them the lesson is very difficult to understood, and they didn't understand the topic being discussed.

\section{B. Suggestions}


Based on the results, the researcher would like to propose some suggestions as follows:

1) For the teacher: to make the interaction effective in using English as a target language in the study, the teacher should give more support and familiarize the students to using English in the classroom interaction. In the classroom interaction it is better if the teacher not only spend the teaching and learning time by explaining the topic or asking question to the students about the topic, but also can organize some activities for the students. For example: teacher asks the students to make a group and discussion about the topic giving by the teacher. After having discussion, each group presents their discussion results in front of the class and the other students can ask questions to the presenter. This activity can attract the student to be active in the classroom.

2) For the students: they should make themselves familiarize and brave to using English in the classroom interaction.

3) For the next researcher: for the next researcher that want to apply Flanders model in the teaching learning process. The study of teacher and student talk in the classroom interaction can be extended by conducting the research in different content. The next researcher may investigate the dominant type of teacher and student talk in English classroom interaction, investigate the advantages and disadvantages of teacher and student talk in classroom interaction 


\section{REFERENCES}

Bogdan, Robert dan Taylor (2006). Pengantar Metode Penelitian Kualitatif, Terjemahan oleh Arief Rurchan, Surabaya: Usaha Nasional, 1992.

Cook, V. (2000). Second Language Learning and Language Teaching (2nd Edition). Beijing: Foreign Language Teaching and Research Press.

Dagarin, M. (2004). Classroom Interaction and Communication Strategies in Learning English as a Foreign. Ljubljana: Slovene Association for the Study Of English.

Flanders, N. A. (1970). Analyzing Teacher Behavior. New York: Addison Wesley.

Liu, Y. F., \& Zhao, Y. Q. (2010). A study of teacher talk in interactions in English classes. Chinese Journal of Applied Linguistics, 33(2), 76-86.

Xiaou, M. (2006). A Dissertation; Teacher Talk and EFL in University Classrooms. The Asian EFL journal. Retrieved on April 4th, 2018

from http://journal.upi.edu/file/lianifinal.33-48.pdf

Yanfen, L. \&Yuqin, Z. (2010). A Study of Teacher Talk in Interactions in English Classes .Chinese Journal of Applied Linguistics, Vol.33, No. 2. 